\title{
Conformational and FTIR analyses of 2,3-dimethoxyphenylboronic acid
}

\section{2,3-dimetoksifenilboronik asit molekülünün konformasyon ve FTIR analizi}

\author{
Duygu BILGE ${ }^{1 *}$ (D)
}

1Physics Department, Faculty of Science, Ege University, İzmir, Turkey.

duygu.bilge@ege.edu.tr

\begin{abstract}
The experimental and theoretical investigations of solvent effect on conformational structure and the hydroxyl stretching vibration of 2,3-dimethoxyphenylboronic acid (2,3-dmpba; $\left.\mathrm{C}_{6} \mathrm{H}_{3}\left(\mathrm{OCH}_{3}\right)_{2} \mathrm{~B}(\mathrm{OH})_{2}\right)$ molecule were studied by Fourier transform infrared (FTIR) spectroscopy and density functional theory (DFT). Calculations were performed by four conformational isomers of the title compound in eighteen different organic solvents by the polarizable continuum model (PCM). Scaled quantum mechanical (SQM) method was performed for the vibrational analysis. Most stable conformational isomer of the compound is independent of the solvent effect. Results of SQM method are very successful in determining the solvent effect on vibrational frequency. Experimental and theoretical findings from the present search will be useful to understand structural characteristics of phenylboronic acid derivatives.
\end{abstract}

Keywords: Phenylboronic acid derivatives, FTIR, DFT, SQM, Solvent effect

\section{Introduction}

Boronic acid is a compound related to boric acid in which one of the three hydroxyl groups is replaced by an alkyl or aryl group. Boron and boronic acid-based include large number of potentials of related application in medicine, biology, material science and supramolecular or analytical chemistry [1]-[2]. A variety of typical properties of boronic acids enable them to be well suitable for practices in biomedicine [2]. Polymers including boronic acid have a wide range of uses in various biomedical applications such as management of HIV, obesity, diabetes, and cancer [3].

Phenylboronic acid (PBA) containing a phenyl substituent is an example of boronic acid. PBA and its derivatives have also attracted much attention as modifier of layer by layer films or microcapsules [4]. Molecular characteristics of PBA and its some derivatives have been studied for years. Crystal and molecular structures or some spectroscopic properties of PBA [5] and its dimer [6], diphenyl phenylboronate [7], 3-fluorophenylboronic acid [8], 4-chloro-or-bromophenylboronic acid [9], 2- and 4-iodo-phenylboronic acid [9], 2,4-difluorophenylboronic acid [10], 3-formylphenylboronic acid [11], 3-aminophenylboronic acid [12] were investigated.

There are many theoretical and experimental structural investigations on boronic acid derivatives such as 4-pyridineboronic acid [13], methylboronic acid [14], acenaphthene-5-boronic acid [15] and 2-thienylboronic acid [16]. Furthermore, conformational, vibrational or electronic properties of phenylboronic acid derivatives such as 4-chloroor -bromo-phenylboronic acid [17], 3,4-dichlorophenylboronic acid [18], 2,4- or 2,6-dimethoxy phenylboronic acids [19],[20],
Öz

2,3-dimetoksifenil boronik asit molekülünün (2,3-dmpba; $\left.\mathrm{C}_{6} \mathrm{H}_{3}\left(\mathrm{OCH}_{3}\right)_{2} \mathrm{~B}(\mathrm{OH})_{2}\right)$ konformasyonel yapiss ve hidroksil (OH) gerilmeleri titreşimi üzerindeki çözücü etkisi Fourier dönüşümlü kızılötesi spektroskopisi (FTIR) ve yoğunluk fonksiyonel teorisi (YFT) ile birlikte hem deneysel hem de teorik olarak araştırılmıştır. Hesaplamalar polarize süreklilik modeli (PCM) kullanılarak on sekiz farklı organik çözücüde ve bileșiğin dört konformasyonel izomeri üzerinde odaklanmıștır. Titreșim analizleri için skalanmış kuantum mekanik model (SQM) kullanılmıștır. Ele alınan molekülün en kararlı konformasyonel izomeri çözücü etkisinden bağımsızdır. SQM metodu titreșim frekansları üzerindeki çözücü etkisini belirlemede oldukça başarılıdır. Bu çalışmadan elde edilen deneysel ve teorik tüm bulgular fenil boronik asit türevlerinin yapısal karakteristiklerini anlamada faydall olacaktır.

Anahtar kelimeler: Fenilboronik asit türevleri, FTIR, DFT, SQM, Çözücü etkisi

2,3-difluorophenylboronic [21], 3-bromophenylboronic acid [22], 3,5-difluorophenylboronic acid [23], 3-fluorophenylboronic acid [24], 4-mercaptophenylboronic acid [25], 4-carboxy phenylboronic acid [26], 3-(acrylamido)phenylboronic acid [27], 5-bromo-2ethoxyphenylboronic acid [28] and pentafluorophenylboronic acid [29] were reported by combining both experimental and theoretical works. This research is a continuation of these previous studies [17]-[29] and according to the detailed literature survey there is no any theoretical or experimental studies on the structural and vibrational properties of 2,3-dmpba. The detailed analysis was performed to examine the solvent effect on conformational isomerism of 2,3-dmpba. Further, the frequencies of hydroxyl stretch vibrations of the compound were reported by FTIR and DFT studies.

\section{Experimental}

2,3-dmpba was commercially obtained from Sigma Aldrich and chloroform, methanol, ethanol and dichloromethane solvents were procured from Merck. FTIR spectrum of free and solid 2,3-dmpba wereoptimi reported via Potassium Bromide (KBr) pellet technique by Perkin Elmer Frontier FT-IR spectrophotometer at a resolution of $2 \mathrm{~cm}^{-1}$. Infrared spectra of 2,3-dmpba in solutions were recorded by a deuterated triglycine sulfate detector. Concentrations of 2,3-dmpba in the pure solvents ranged from 0.28 to $0.31 \mathrm{~mol} / \mathrm{l}$. Solvents of $25 \mu \mathrm{l}$ were placed between $\mathrm{CaF}_{2}$ windows whose cell thickness was $12 \mu \mathrm{m}$. 


\section{Calculational details}

Many possible conformational isomers could be proposed for 2,3-dmpba molecule. However, the discussion in this research is limited to cis-cis $(C C)$, cis-trans $(C T)$, trans-cis $(T C)$ and transtrans (TT) forms (Figure 1). Gaussian 09 was used for all calculations [30]. The optimized molecular structures were viewed with the GaussView program [31]. Calculations were performed by DFT method at B3LYP/6-31++G** in the gas phase and solutions. PCM model was employed to assess the solvent effect [32]. After, optimization processes were repeated with no geometric constraints until imaginary frequencies were not seen, calculations were performed for vibrational frequency under the same theory. Harmonic vibrational frequencies were scaled according to 0.955 [33] and SQM [34],[35]. Mole fractions for the isomers were calculated as given before [36],[37].

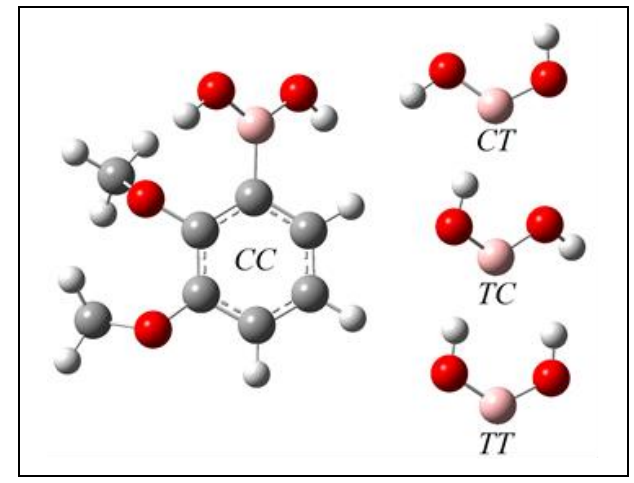

Figure 1: Conformational isomers of 2,3-dmpba.

\section{Results and discussion}

Optimization energies of four isomers of the compound in eighteen different solvents are given in Table 1. Optimization energy vs. solvent dielectric constant plot of 2,3-dmpba in $C T$ form are also depicted in Figure 2.

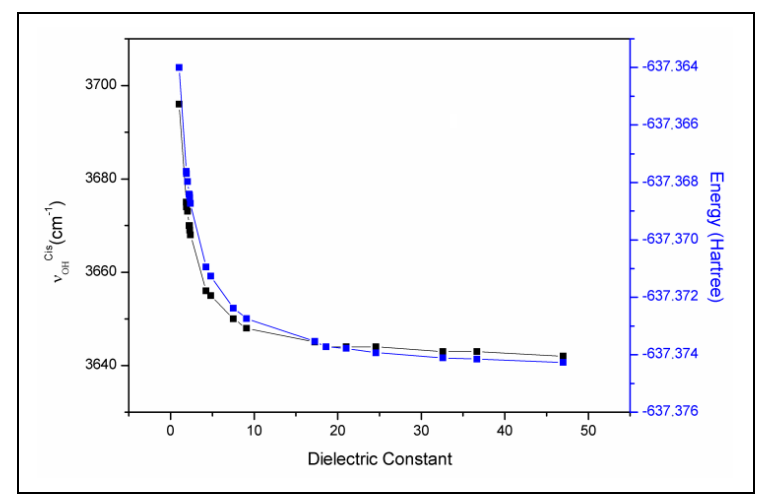

Figure 2: Plot of optimized energy and $\mathrm{OH}$ stretching frequency vs. dielectric constant.

Solvation is the process of interaction between solvent and solute molecules and is in part due to the attraction of a charge for a dipole. If the solute has polarity, solvent molecules will be thus drawn to the solute molecules. The greater the polarity of the solvent, the more the attraction is and therefore the more close attraction of the solvent molecules to the solute molecules is. Thus more electrostatic work is performed and so is more energy lost by the system, which inevitably turns more stable [38]. As seen from Table 1 and Figure 2, since dielectric constant of the solvent increases for the all forms, the molecule becomes more stable.

According to direction of various substituents in the gas phase, 3,4-dichloro [18], 2,4-dimethoxy [19], 2,3-difluoro [21] and 3,5-difluoro phenylboronic acid [23] prefer to $C T$ form whereas the CC conformer is the most stable for 2,6-dimethoxy phenylboronic acid [20]. Optimized relative energies and mole fractions for all forms of 2,3-dmpba in different medium are listed in Table 2. Computed optimize energies indicate that the CT form is more stable than $C C, T C$ and TT forms by 7.77-9.57 $\mathrm{kcal} / \mathrm{mol}$, 9.11-10.63 kcal/mol and 10.10-13.97 $\mathrm{kcal} / \mathrm{mol}$ correspondingly. According to results of mole fraction computations of isomers, the title molecule prefers to $C T$ conformational isomer with the probability of $100 \%$ for all medium (Table 2).

Table 3 presents the calculated lengths of hydroxyl bond and dipole moments of 2,3-dmpba, from which the $\mathrm{OH}$ bond lengths in $C T$ form are seen to exhibit a linear correlations with the hydroxyl stretching frequencies of the compound as $\mathrm{R}^{2}=0.99484$ (C) and 0.99554 (T). Dipole moment of the compound increases gradually by solvent polarity. It is in agreement with the literature. However, it is inversely proportional with the hydroxyl stretching frequencies. As seen from Figure 3, there is good and linear correlation between $\mathrm{OH}$ stretching frequencies and dipole moments $\left(R^{2}=0.99466\right)$.

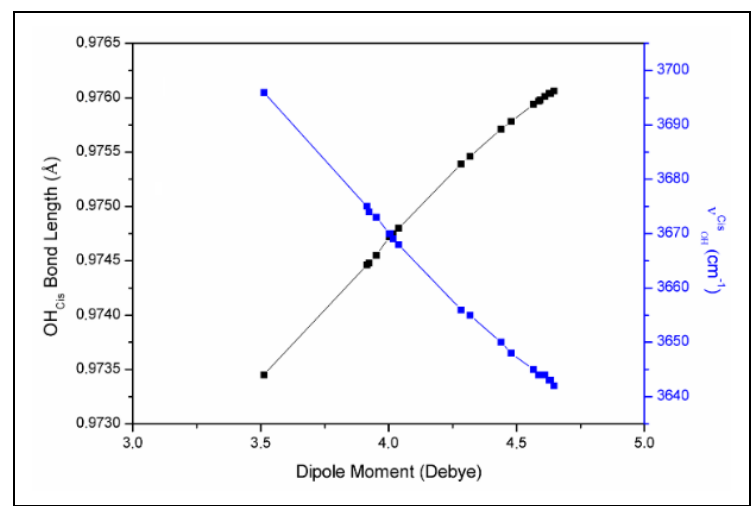

Figure 3: Plot of $\mathrm{OH}$ bond length and stretching frequency vs. dipole moment.

Length of $\mathrm{OH}$ bond increases as the polarity of the solvent does. Hydroxyl stretching frequency should therefore decrease. It follows from Table 3 that this requirement is significantly fulfilled for the compound and $\mathrm{OH}$ frequencies decreases by increases in the bond lengths $\left(\mathrm{R}^{2}=0.99956\right)$. Hydroxyl stretching frequencies are inversely proportional to the polarity of the solvent (Figure 2).

$\mathrm{OH}$ stretching vibrations of the investigated molecule needs to special attention. Once these bands of some PBA derivatives are investigated, they are comprehensible and this suggests that the intramolecular hydrogen bondings occur in different environments of boronic acids [25]. The hydroxyl stretching bands in the infrared spectra of free 3,4-dichlorophenylboronic acid [18], 2,4- and 2,6-dimethoxyphenylboronic acid [19],[20], 2,3-difluorophenylboronic acid [21] and 5-bromo-2ethoxyphenylboronic acid [28] were observed at 3465/3425, $3480 / 3339,3335$ and $3400 / 3332$ and $3371 \mathrm{~cm}^{-1}$ correspondingly. However, there is no any peak for 3,5difluorophenylboronic acid [14]. OH stretching band of free 2,3dmpba is shown at $3368 \mathrm{~cm}^{-1}$ for the solid phase. This observation is consistent with previously reported paper 
[18]-[21],[28]. As seen from Table 4, they are observed at 3468 $\mathrm{cm}^{-1}, 3351 \mathrm{~cm}^{-1}, 3350 \mathrm{~cm}^{-1}$ and $3351 \mathrm{~cm}^{-1}$ in chloroform, dichloromethane, ethanol and methanol, respectively, as one strong and broad band. These experimental $\mathrm{OH}$ stretching frequencies also decrease by increasing of the dielectric constant of the solvent.

In Table 4, theoretical $\mathrm{OH}$ stretching vibrations scaled by literature coefficient and SQM are also given together with their experimental values. Correlation values between the experimental and computed vibrational frequencies are found to be 0.76684 for scaling factor and 0.99872 for SQM. The biggest difference between the experimental and theoretical frequencies is $133 \mathrm{~cm}^{-1}$ for scaling factor in literature and $29 \mathrm{~cm}^{-1}$ for SQM. Hence, there is a poor agreement between the theoretically scaled frequencies by scaling factor of the B3LYP/6-31++G** and those obtained experimentally. However, the predicted values by SQM show a good correlation with experimental data and this method constitutes a reliable complement the understanding of vibrational bands of the investigated compound.

Table 1: Optimization energy (Hartree) of 2,3-dmpba in various medium.

\begin{tabular}{ccccc}
\hline \multirow{2}{*}{ Medium } & \multicolumn{5}{c}{$2,3-\mathrm{dmpba}$} \\
\cline { 2 - 5 } & $-6 C$ & -637.34173799 & -637.36400100 & -637.34706046 \\
Gas phase & -637.34875320 & -637.34696008 & -637.36762019 & -637.35111167 \\
n-hexane & -637.35319394 & -637.34707820 & -637.36769830 & -637.35120243 \\
n-heptane & -637.35329185 & -637.34748170 & -637.36796394 & -637.35151230 \\
Cyclohexane & -637.35362546 & -637.34815308 & -637.36840238 & -637.35202775 \\
1,4-dioxane & -637.35417813 & -637.34821172 & -637.36844044 & -637.35207277 \\
Tetrachloromethane & -637.35422626 & -637.34834717 & -637.36852819 & -637.35217673 \\
Benzene & -637.35433731 & -637.34866174 & -637.36873128 & -637.35241822 \\
Toluene & -637.35459477 & -637.35235039 & -637.37094067 & -637.35514797 \\
Diethylether & -637.35743615 & -637.35288547 & -637.37125964 & -637.35556333 \\
Chloroform & -637.35785270 & -637.35480220 & -637.37238275 & -637.35706528 \\
Tetrahydrofuran & -637.35933333 & -637.35541587 & -637.37273492 & -637.35754950 \\
Dichloromethane & -637.35980249 & -637.35684683 & -637.37354195 & -637.35868563 \\
2-butanol & -637.36088794 & -637.35718054 & -637.37372740 & -637.35895230 \\
2-propanol & -637.36113953 & -637.35727806 & -637.37378141 & -637.35903041 \\
Acetone & -637.36121295 & -637.35754951 & -637.37393128 & -637.35924822 \\
Ethanol & -637.36141711 & -637.35785914 & -637.37410146 & -637.35949737 \\
Methanol & -637.36164963 & -637.35794572 & -637.37414888 & -637.35956717 \\
Acetonitrile & -637.36171457 & -637.35816643 & -637.37426945 & -637.35974535 \\
Dimethylsulfoxide & -637.36187993 &
\end{tabular}

Table 2: Relative energy and mole fraction for 2,3-dmpba in various medium.

\begin{tabular}{|c|c|c|c|c|c|c|c|c|}
\hline \multirow{2}{*}{ Medium } & \multicolumn{4}{|c|}{ Relative energy (kcal/mol) } & \multicolumn{4}{|c|}{ Mole fraction (\%) } \\
\hline & $C C$ & $T T$ & $C T$ & $T C$ & $C C$ & $T T$ & $C T$ & $T C$ \\
\hline Gas phase & 9.57 & 13.97 & - & 10.63 & 0 & 0 & 100 & 0 \\
\hline n-hexane & 9.05 & 12.96 & - & 10.36 & 0 & 0 & 100 & 0 \\
\hline n-heptane & 9.04 & 12.94 & - & 10.35 & 0 & 0 & 100 & 0 \\
\hline Cyclohexane & 9.00 & 12.85 & - & 10.32 & 0 & 0 & 100 & 0 \\
\hline 1,4-dioxane & 8.93 & 12.71 & - & 10.28 & 0 & 0 & 100 & 0 \\
\hline Tetrachloromethane & 8.92 & 12.70 & - & 10.27 & 0 & 0 & 100 & 0 \\
\hline Benzene & 8.90 & 12.66 & - & 10.26 & 0 & 0 & 100 & 0 \\
\hline Toluene & 8.87 & 12.59 & - & 10.24 & 0 & 0 & 100 & 0 \\
\hline Diethylether & 8.47 & 11.67 & - & 9.91 & 0 & 0 & 100 & 0 \\
\hline Chloroform & 8.41 & 11.53 & - & 9.85 & 0 & 0 & 100 & 0 \\
\hline Tetrahydrofuran & 8.19 & 11.03 & - & 9.61 & 0 & 0 & 100 & 0 \\
\hline Dichloromethane & 8.12 & 10.87 & - & 9.53 & 0 & 0 & 100 & 0 \\
\hline 2-butanol & 7.94 & 10.48 & - & 9.32 & 0 & 0 & 100 & 0 \\
\hline 2-propanol & 7.90 & 10.38 & - & 9.27 & 0 & 0 & 100 & 0 \\
\hline Acetone & 7.89 & 10.36 & - & 9.26 & 0 & 0 & 100 & 0 \\
\hline Ethanol & 7.85 & 10.28 & - & 9.21 & 0 & 0 & 100 & 0 \\
\hline Methanol & 7.81 & 10.19 & - & 9.16 & 0 & 0 & 100 & 0 \\
\hline Acetonitrile & 7.80 & 10.17 & - & 9.15 & 0 & 0 & 100 & 0 \\
\hline Dimethylsulfoxide & 7.77 & 10.10 & - & 9.11 & 0 & 0 & 100 & 0 \\
\hline
\end{tabular}


Table 3: Dipole moment, 0-H stretching and bond length of 2,3-dmpba (CT).

\begin{tabular}{|c|c|c|c|c|c|}
\hline Medium & $\mu$ (Debye) & O-H: $C(\AA)$ & $v_{\mathrm{OH}}: C\left(\mathrm{~cm}^{-1}\right)$ & O-H: $T(\AA)$ & $v_{\mathrm{OH}}: T\left(\mathrm{~cm}^{-1}\right)$ \\
\hline Gas phase & 3.513 & 0.97345 & 3696 & 0.96613 & 3846 \\
\hline n-hexane & 3.915 & 0.97446 & 3675 & 0.96653 & 3841 \\
\hline n-heptane & 3.924 & 0.97448 & 3674 & 0.96653 & 3840 \\
\hline Cyclohexane & 3.953 & 0.97455 & 3673 & 0.96656 & 3840 \\
\hline 1-4-dioxane & 4.003 & 0.97472 & 3670 & 0.96669 & 3838 \\
\hline Tetrachlorometha & 4.007 & 0.97473 & 3670 & 0.96670 & 3838 \\
\hline Benzene & 4.017 & 0.97475 & 3669 & 0.96671 & 3838 \\
\hline Toluene & 4.039 & 0.97480 & 3668 & 0.96673 & 3838 \\
\hline Diethylether & 4.283 & 0.97539 & 3656 & 0.96704 & 3833 \\
\hline Chloroform & 4.318 & 0.97546 & 3655 & 0.96709 & 3833 \\
\hline Tetrahydrofuran & 4.440 & 0.97571 & 3650 & 0.96723 & 3831 \\
\hline Dichloromethane & 4.479 & 0.97578 & 3648 & 0.96727 & 3830 \\
\hline 2-butanol & 4.567 & 0.97594 & 3645 & 0.96737 & 3829 \\
\hline 2-propanol & 4.587 & 0.97597 & 3644 & 0.96739 & 3828 \\
\hline Acetone & 4.593 & 0.97598 & 3644 & 0.96739 & 3828 \\
\hline Ethanol & 4.610 & 0.97601 & 3644 & 0.96741 & 3828 \\
\hline Methanol & 4.628 & 0.97604 & 3643 & 0.96743 & 3828 \\
\hline Acetonitrile & 4.634 & 0.97604 & 3643 & 0.96744 & 3828 \\
\hline Dimethylsulfoxide & 4.647 & 0.97606 & 3642 & 0.96745 & 3827 \\
\hline
\end{tabular}

Table 4: Comparison of $\mathrm{OH}$ stretching frequencies $\left(\mathrm{cm}^{-1}\right)$.

\begin{tabular}{cccc}
\hline Medium & Exp. $\mathrm{vOH}$ & $\mathrm{vOH}^{1}(C)$ & $\mathrm{VOH}^{2}(C)$ \\
\hline Chloroform & 3468 & 3491 & 3440 \\
Dichloromethane & 3351 & 3484 & 3380 \\
Ethanol & 3350 & 3480 & 3379 \\
Methanol & 3351 & 3479 & 3375 \\
\hline
\end{tabular}

$v_{0 H^{1}}(C)$ and $v_{0}{ }^{2}(C)$ are scaled frequencies by 0.955 [33] and SQM $[34,35]$.

\section{Conclusions}

Theoretical and experimental works have been performed by using DFT and FTIR to investigate solvent effect on the structure and hydroxyl stretching vibration of 2,3-dmpba as phenylboronic acid derivatives. There is no solvent effect on conformational isomers of the compound. Solvent induced $\mathrm{OH}$ frequencies are inversely proportional with the dipole moment, bond length and dielectric constant. Unscaled and scaled frequencies by B3LYP/6-31++G** have poor correlations with experimental data whereas SQM results are in excellent agreement and it is very successful in revealing the dielectricinduced solvent effect on the vibrational frequency.

\section{Acknowledgements}

This work was supported by Research Fund of the Ege University (Project Number: 2016-FEN-032).

\section{References}

[1] Hall DG. Boronic Acids: Preparation and Applications in Organic Synthesis and Medicine. Alberta, Canada, Wiley, 2005.

[2] Yang W, Gao X, Wang B. Biological and medicinal applications of boronic acids. Editor: Hall DG. Preparation and Applications in Organic Synthesis and Medicine, 481-512, Alberta, Canada, Wiley, 2005.
[3] Cambre JN, Sumerlin BS. "Biomedical applications of boronic acid polymers". Polymer, 52(21), 4631-4643, 2011.

[4] Wang B, Yoshida K, Sato K, Anzai J. "Phenylboronic acid-functionalized layer-by-layer assemblies for biomedical applications". Polymers, 9(6), 202, 2017.

[5] Rettig SJ, Trotter J. "Crystal and molecular structure of phenylboronic acid, C6H5B(OH)2". Canadian Journal of Chemistry, 55(17), 3071-3075, 1977.

[6] Cyran'ski MK, Jezierska A, Klimentowska P, Panek JJ, Sporzyns'ki AA. "Impact of intermolecular hydrogen bond on structural properties of phenylboronic acid: quantum chemical and X-ray study". Journal of Physical Organic Chemistry, 21(6), 472-482, 2008.

[7] Faniran JN, Shurvell HF. "Infrared spectra of phenylboronic acid (normal and deuterated) and diphenyl phenylboronate". Canadian Journal of Chemistry, 46(12), 2089-2095, 1968.

[8] Wu YM, Dong CC, Liu S, Zhu HJ, Wu YZ. "3-Fluorophenylboronic acid". Acta Crystallographica Section E, 62(10), 4236-4237, 2006.

[9] Shimpi MR, SeethaLekshmi N, Pedireddi VR. "Supramolecular architecture in some 4halophenylboronic acids". Crystal Growth\& Design, 7(10), 1958-1963, 2007.

[10] Rodriguez-Cuamatzi P, Tlahuext H, Höpfl H. "2,4-Difluorophenylboronic acid". Acta Crystallographica Section E, 65(1), 44-45, 2009. 
[11] Zarychta B, Zaleski J, Sporzynski A, Dabrowski M, Serwatowski J. "3-Formylphenylboronic acid". Acta Crystallographica Section C, 60(5), 344-345, 2004.

[12] Vega A, Zarate N, Tlahuext H, Höpfl H. "3-aminophenylboronic acid monohydrate". Acta Crystallographica Section E, 66(6), 1260-1267, 2010.

[13] Kurt M, Sertbakan TR, Özduran M. "An experimental and theoretical study of molecular structure and vibrational spectra of 3-and 4-pyridineboronic acid molecules by density functional theory calculations". Spectrochimica Acta Part A: Molecular and Biomolecular Spectroscopy, 70(3), 664-673, 2008.

[14] Rani U, Karabacak M, Tanrıverdi O, Kurt M, Sundaraganesan N. "The spectroscopic (FTIR, FT-Raman, NMR and UV), first-order hyperpolarizability and HOMO-LUMO analysis of methylboronic acid". Spectrochimica Acta Part A: Molecular and Biomolecular Spectroscopy, 92(15), 67-77, 2012.

[15] Karabacak M, Sinha L, Prasad O, Asiri AM, Cinar M. "An experimental and theoretical investigation of Acenaphthene-5-boronic acid: conformational study, NBO and NLO analysis, molecular structure and FT-IR, FT-Raman, NMR and UV spectra". Spectrochimica Acta Part A: Molecular and Biomolecular Spectroscopy, 115, 753-766, 2013.

[16] Sachan AK, Pathak SK, Sinha L, Prasad O, Karabacak M, Asiri AM. "A combined experimental and theoretical investigation of 2-Thienylboronic acid: Conformational search, molecular structure, NBO, NLO and FT-IR, FT-Raman, NMR and UV spectral analysis". Journal of Molecular Structure, 1076, 639-650, 2014.

[17] Kurt M. "DFT simulations and vibrational spectra of 4-chloro and 4-bromophenylboronic acid molecules". Journal of Raman Spectroscopy, 40(1), 67-75, 2009.

[18] Kurt M, Sertbakan TR, Özduran M, Karabacak M. "Infrared and Raman spectrum, molecular structure and theoretical calculation of 3,4-dichlorophenylboronic acid". Journal of Molecular Structure, 92(1), 178-187, 2009.

[19] Alver Ö. "DFT, FT-Raman, FT-IR, solution and solid state NMR studies of 2,4-dimethoxyphenylboronic acid". Comptes Rendus Chimie, 14(5), 446-455, 2011.

[20] Alver Ö, Parlak C. "DFT, FT-Raman, FT-IR, liquid and solid state NMR studies of 2,6-dimethoxyphenylboronic acid". Vibrational Spectroscopy, 54(1), 1-9, 2010.

[21] Karabacak M, Kose E, Atac A, Cipiloglu MA, Kurt M. "Molecular structure investigation and spectroscopic studies on 2,3-difluorophenylboronic acid: A combined experimental and theoretical analysis". Spectrochimica Acta Part A: Molecular and Biomolecular Spectroscopy, 97, 892-908, 2012.

[22] Karabacak M, Kose E, Atac A, Sas EB, Asiri AM, Kurt M. "Experimental (FT-IR, FT-Raman, UV-Vis, 1H and 13C NMR) and computational (density functional theory) studies on 3-bromophenylboronic acid". Journal of Molecular Structure, 1076, 358-372, 2014.

[23] Karabacak M, Kose E, Atac A, Asiri AM, Kurt. "Monomeric and dimeric structures analysis and spectroscopic characterization of 3,5-difluorophenylboronic acid with experimental (FT-IR, FT-Raman, 1H and 13C NMR, UV) techniques and quantum chemical calculations". Journal of Molecular Structure, 1058, 79-96, 2014.
[24] Karabacak M, Kose E, Sas EB, Kurt M, Asiri AM, Atac A. "DFT calculations and experimental FT-IR, FT-Raman, NMR, UV-Vis spectral studies of 3-fluorophenylboronic acid". Spectrochimica Acta Part A: Molecular and Biomolecular Spectroscopy, 136, 306-320, 2015.

[25] Parlak C, Ramasami P, Tursun M, Rhyman L, Kaya MF, Atar N, Alver Ö, Şenyel M. "4-Mercaptophenylboronic acid: Conformation, FT-IR, Raman, OH stretching and theoretical studies". Spectrochimica Acta Part A: Molecular and Biomolecular Spectroscopy, 144, 131-138, 2015.

[26] Dikmen G, Alver Ö, Parlak C. "NMR determination of solvent dependent behavior and XRD structural properties of 4-carboxy phenylboronic acid: A DFT supported study". Chemical Physics Letters, 698, 114-119, 2018.

[27] Alver Ö, Kaya MF, Dikmen G. "Structural characterization, solvent effects on nuclear magnetic shielding tensors, experimental and theoretical DFT studies on the vibrational and NMR spectra of 3(acrylamido)phenylboronic acid". Journal of Molecular Structure, 1102, 285-294, 2015.

[28] Sas EB, Kose E, Kurt M, Karabacak M. "FT-IR, FT-Raman, NMR and UV-Vis spectra and DFT calculations of 5-bromo2-ethoxyphenylboronic acid (monomer and dimer structures)". Spectrochimica Acta Part A: Molecular and Biomolecular Spectroscopy, 137, 1315-1333, 2015.

[29] Kurt M, "An experimental and theoretical study of molecular structure and vibrational spectra of pentafluorophenylboronic acid molecule by density functional theory and ab initio Hartree Fock calculations". Journal of Molecular Structure, 874(1), 159-169, 2008.

[30] Frisch MJ, Trucks, GW, Schlegel HB, Scuseria GE, Robb MA, Cheeseman JR, Scalmani G, Barone V, Mennucci B, Petersson GA, Nakatsuji H, Caricato M, Li X, Hratchian HP, Izmaylov AF, Bloino J, Zheng G, Sonnenb DJ. Gaussian 09, Revision A.1, Gaussian, Inc., Wallingford, USA, 2008.

[31] Dennington RD, Keith TA, Millam JM. GaussViev 5.0.8, Gaussian, Inc., Wallingford, USA, 2008.

[32] Miertus S, Scrocco E, Tomasi T. "Electrostatic interaction of a solute with a continuum. A direct utilizaion of $A B$ initio molecular potentials for the prevision of solvent effects". Chemical Physics, 55(1), 117-129, 1981.

[33] Balcı K, Akyüz S. "A vibrational spectroscopic investigation on benzocaine molecule". Vibrational Spectroscopy, 48(2), 215-218, 2008.

[34] Baker J, Jarzecki AA, Pulay P. “Direct scaling of primitive valence force constants: an alternative approach to scaled quantum mechanical force fields". The Journal of Physical Chemistry A, 102(8), 1412-1424, 1998.

[35] Rauhut G, Pulay P. "Transferable scaling factors for density functional derived vibrational force fields". The Journal of Physical Chemistry, 99(10), 3093-3100, 1995.

[36] Parlak C. "Theoretical and experimental vibrational spectroscopic study of 4-(1-Pyrrolidinyl) piperidine". Journal of Molecular Structure, 966(1), 1-7, 2010.

[37] Tursun M, Parlak C. "Conformation stability, halogen and solvent effects on CO stretching of 4-chloro-3halogenobenzaldehydes". Spectrochimica Acta Part A: Molecular and Biomolecular Spectroscopy, 141, 58-63, 2015.

[38] Sharma RK. Stereochemistry. New Delhi, India, Discovery Publishing House, 2007. 